\title{
Changes in transport activity regulation in the context of the coronavirus pandemic
}

\author{
Maxim Makhiboroda ${ }^{1, *}$, Ekaterina Ananyeva ${ }^{1}$, and Ing. Petr Doucek ${ }^{2}$ \\ ${ }^{1}$ Institute of The Academy of the Federal penitentiary service of Russia, Department of civil law and \\ procedure, 390000, Ryazan, Sennaya Str., 1, Russia \\ ${ }^{2}$ University of Economics in Prague, Department of Systems Analysis (FIS), 13067 Praha, 3 nám. W. \\ Churchilla 1938/4, Czech Republic
}

\begin{abstract}
In the article, the authors consider the activities of transport companies in the context of the coronavirus pandemic. The main research concerns the organization of the process of replacing the time of service provision by contractors when they are in emergency situations or when it is impossible to fulfill transport contracts at the set time. For the first time in the history of mankind, legal states are faced with the need to immediately close borders, prohibit citizens from leaving not only their own state, but also their place of residence in whole. Digitalization of the processes of instant solution of issues related to the activities of transport organizations turned out to be inoperable in relation to the realities of the new time. The state, trying not to destroy the country's economic system and preserve the transport system, was forced to immediately introduce online services and other technological resources. Analysis of changes in the accompanying documentation and regulations at the level of federal laws, departmental and local regulations shows that civil society and its institutions in the future will not be able to do without thoughtful innovations and regulatory support for the technical component of transport regulation.
\end{abstract}

\section{Introduction}

For the first time since the existence of statehood and mass diseases in the XXI century, humanity faced a real threat of a decline in the number of people living in different countries and on different continents. Borders between states have never been completely closed. But the realities of the new phenomenon dictate such conditions. However, states continue to develop and interact, the activities of various bodies and institutions continue, and the service sector, although on a limited scale, does not stop its activities, but moves to a new level and develops information network platforms[1,2]. However, there are still activities that require direct participation related to movement over certain distances.

The situation that has developed in some regions and in almost all developed countries of the world has shown that humanity, in its sufficiently developed civilization, is not ready

\footnotetext{
${ }^{*}$ Corresponding author: a.e.o.77@yandex.ru
} 
to abruptly stop moving both over sufficiently remote distances and in one locality. The lack of a legislative framework that regulates these issues in the mode of accelerated development and instant legislative initiative has led to the development of regulation of issues related to the activities of citizens, entrepreneurs, companies, bodies, organizations and institutions in the context of the pandemic. Moreover, it became impossible to cover all the issues immediately. However, in Russia, the first wave of decisions was successful, although it was not able to initially prevent the insolvency of individual business entities.

Based on the decision of state authorities, namely the Government of the Russian Federation[3] and the adoption of relevant regulatory legal acts at the regional level[4] on the introduction of restrictive measures and addressing the issue of preventing the spread of the virus; in the first months one of the most difficult situations was observed in the transport sphere. Flights were canceled at the same time, except for planes carrying citizens of the Russian Federation from abroad to their homeland, and railway and bus services were almost completely stopped. Naturally, this led to violations of the terms of millions of contracts for deliveries, transportation, etc. It stands to mention that this situation has developed not only in Russia but has affected almost all countries of the world. In order to maintain the self-isolation regime, some regions have stopped activity of transport companies that carry out water, sea, cargo and passenger transportation. In addition, to maintain the self-isolation regime, the state government introduced non-working days that are mandatory for all citizens [5].

However, this situation was generally unique and occurred for the first time, as evidenced by the lack of regulatory control and algorithm of actions in such situations. These include the responsibility of individuals for non-compliance with the standards of living in a pandemic[6], the responsibility of state structures and officials for late resolution of issues related to citizens' requests, and, finally, the solution of problems related to losses and liability for non-fulfillment of contract terms, as well as improper fulfillment of conditions of transport obligations.

\section{Materials and methods}

For a full consideration of the issue, it is necessary to refer initially to the definitions and norms of civil law and transport legislation in whole, which regulates the activities of legal entities and individual entrepreneurs in transport, as well as the activities of state transport organizations. Transport obligations are considered in domestic civil legislation as obligations under which the carrier must perform both legal and practical actions to move the passenger, baggage and cargo in favor of the shipper, and the latter must pay for these actions.

There is a concept of transport services. It is closely related to the definition of transport obligations, as it is generally part of it. This means certain activities of a transport company or individual who owns a vehicle or vehicles and is able to arrange transportation of people, baggage or cargo over a certain distance with a price set for such transportation.

It is worth paying attention to the fact that the issues of providing transport services are fixed in civil legislation, namely in article 128 of the Civil Code of the Russian Federation. However, it does not give an exact definition, but rather refers such services to objects of civil rights. Only the norms of the Tax Code of the Russian Federation provide for the impossibility of transport services to have a material form and determines the time of its provision.

Liability for transport offences is considered in a separate chapter in the Code of administrative violations. At the same time, issues related to the liability of the parties in 
the provision of transport services under the contract are referred to the jurisdiction of civil legislation.

When considering the issues of liability for non-fulfillment of transport obligations, it is necessary to refer to the contract named in the domestic legislation. But in practice the contract on transport services rendering referred to various contracts, including transport, forwarding, vehicle rental with the crew, chartering, transportation, paid services. And before considering the issues of legislative regulation of their operation in limited conditions, for example, in emergency situations, or as a result of a pandemic, it is worth paying attention to the fact that all these contracts have a different subject. If, under the terms of the contract, a transport company or an individual delivers cargo - regardless of the terms, this is transportation. Other transport contracts are considered as related to the provision of services, as in the transport expedition contract. Often, in practice, it is possible to meet mixed types of contracts, which complicates their qualification and the decision on the presence or absence of liability of the parties if it is impossible to fulfill the terms of the contract.

In addition to the terms and definitions, as well as the functional division into different branches of legislation for solving certain issues related to transport activities, it is necessary to carefully consider the possibilities of modeling various situations and ways to resolve them acceptable to the parties to the contract. For example, state support measures were applied in various regions to support small and medium-sized businesses in Russia (See table 1)[7].

Table 1. Some business support measures in some regions of Russia

\begin{tabular}{|l|l|}
\hline city of Moscow & Postponement of advance payments for taxes \\
\hline $\begin{array}{l}\text { city of Saint } \\
\text { Petersburg }\end{array}$ & $\begin{array}{l}\text { Exemption from transport tax for individual entrepreneurs in respect } \\
\text { of vehicles that use natural gas as a motor fuel }\end{array}$ \\
\hline the Ryazan region & Benefits for transportation tax \\
\hline $\begin{array}{l}\text { the Novgorod } \\
\text { region }\end{array}$ & Provision of subsidies to passenger carriers \\
\hline city of Sevastopol & $\begin{array}{l}\text { Provision of subsidies from the budget of the city of Sevastopol to } \\
\text { system-forming organizations of the city of Sevastopol for partial } \\
\text { compensation of expenses related to their activities in the conditions } \\
\text { of situation deterioration as a result of the spread of a new } \\
\text { coronavirus infection, including for maintaining employment and } \\
\text { remuneration of their employees }\end{array}$ \\
\hline the Rostov region & $\begin{array}{l}\text { Provision of subsidies to legal entities and individual entrepreneurs } \\
\text { engaged in regular transportation of passengers and luggage by road } \\
\text { and (or) urban land electric transport on municipal and (or) inter- } \\
\text { municipal routes in the Rostov region }\end{array}$ \\
\hline
\end{tabular}

This is not all the measures provided to support business in Russia, broken down by region.

The obtained results of the problem study, reliability and accuracy were provided with general theoretical provisions and their correlation with practical measures. Monitoring changes in operating modes and reducing costs in order to preserve the structures of organizations in the industry under study. Analysis of the work of transport organizations in various regions, the speed of their response to changes in legislation, as well as the analysis of the norms themselves adopted in extreme conditions in order to preserve the structure of the industry requires not only identifying patterns between economic phenomena and processes affecting the transport sector, taking into account the restrictions and prohibitions 
imposed on the basis of the amended legislation, but also forecasting possible repetition of existing situations and introducing proactive actions on the part of not only the management of transport companies, but also preparing the legislative framework as a whole.

\section{Results and discussions}

The situation of transport companies that transport goods, cargo and passengers was quite difficult. In a situation where regional, inter-regional and inter-state communication is almost stopped, and a considerable amount of money has been spent on the activities of such companies, multimillion losses threatened to terminate their activities. This situation leads to questions on who should bear civil liability for losses, and whether it occurs in the field of transport obligations under concluded contracts.

The norms of domestic legislation do not allow the carrier to refer to the coronavirus pandemic as force majeure in cases of changes in the time or date of transport services provision, as well as refusal to provide them. The other party is also deprived of this right when paying for these services, since its impossibility must be objectively confirmed in each specific case. In such circumstances, such issues should be resolved through negotiations and, if there is no consensus, in courts. To resolve such relations (e.g., modification of transport services contract) it is necessary to use articles 451, 416-417 of the Civil Code in pre-trial and judicial procedure, with reference to introduced normative acts (of the President of the Russian Federation, the Government of the Russian Federation) in connection with the pandemic.

In many countries of the world community, as in Russia, the government has taken unprecedented measures of a prohibitive nature. For example, in the field of air travel. Based on such innovations, transport companies were forced to cancel flights, postpone flights to indefinite dates, etc. Only as a result of this, the issues of refund remained unresolved. Most companies have started making refunds for unused tickets in a special way. Since the funds cannot be returned in full, companies began to issue them in the form of a deposit or a voucher. In this case, the deposit was the return of the actual cost of the ticket not to the client's account, but to a virtual account in the personal account of the person who registered with this airline. Such a deposit can be used within 12 months to pay for the cost of a new ticket. But what to do if the client's departure is not possible due to illness, death, or other situations. Other companies convert unused tickets without penalty into open-date tickets. In general, it was possible to claim money for refund only for return tickets, and full compensation conditions do not apply to fares for non-return tickets[8]. Now such issues are relatively settled and if the airline refuses air transportation due to emergencies or changes in the terms of the contract, the air transportation fee is subject to refund to the passenger. In addition, he can transfer it for a ticket to the future[9].

The general rule under Russian civil law as a result of the debtor's delay states that if the performance has lost interest, one can unilaterally withdraw from the contract (cl. 1 art. 310 of the CC RF, cl. 2 art. 405 of the CC RF). In this case, the carrier will not be liable for losses caused by delay in performance of the obligation due to force majeure. In other words, the civil liability of the transport organization under the legislation of the Russian Federation will not occur. However, let's recall that in the Civil Code of the Russian Federation stated that the parties who have suffered losses as a result of legitimate actions by state bodies, local government bodies or officials of these bodies and also other persons, to which the state delegated powers, are entitled to demand from them compensation in cases and order stipulated by the law (art. 16.1 of the CC RF). Regarding transport obligations, the Plenum of the Supreme Court of the Russian Federation clarified that this is possible only in cases where, in 
accordance with the law or other legal acts, privileges or advantages are established for the carriage of goods, passengers and baggage (cl. 5 of art. 790 of the CC RF).

The President of the Russian Federation in connection with the coronavirus pandemic, among the measures to support the economy, announced direct subsidies for losses for industries at risk. Thus, 1.5 billion rubles were allocated from the reserve fund of the government of the Russian Federation in order to provide subsidies for reimbursement of expenses to air transport organizations that export "Russian citizens and citizens of the CIS countries, Abkhazia and South Ossetia entering the territory of Russia in order to further travel to the state of their citizenship"[10]. The subsidies also affected airlines that carry out so-called "export flights" for Russian citizens who are in difficulties in other countries during the coronavirus pandemic [11].

However, for example, the Russian Federation has not taken any restrictive measures in the field of road transport. Almost no restrictions were applied to international transport links[12]. The only thing that was restricted was the entry of foreign citizens to Russia. In this case, there are no force majeure circumstances. However, the question arises, who will reimburse exact the transport organization for losses? In this case, restrictions or prohibitions as a result of the coronavirus pandemic can only be recognized within the framework of a specific performance of the contract (transport obligations), and not for the company's activities as a whole.

In accordance with Russian legislation, as well as based on the existing practice of courts in resolving disputes related to force majeure, such circumstances do not include business risks. Namely, it is impossible to attribute to force majeure or force majeure changes in exchange rates, the deterioration of the economic condition of the enterprise and its bankruptcy, the devaluation of the national currency, which is currently taking into account the closure of borders of different countries due to the coronavirus pandemic. In other legal systems, other rules for the release of debtors from civil liability can be observed, but only in cases where it is impossible to fulfill the obligation.

Individual transport companies and organizations have independently adopted several solutions that are relieving for contractors in order to stabilize the situation at the transportation market. For example, on the official website of JSC "Russian Railways" information was posted, according to which citizens can return tickets without paying a fee, regardless of the group or individual trip. This measure was introduced by the management of Russian Railways in connection with the unfavorable epidemiological situation, since many citizens bought tickets in advance, but due to the circumstances decided to postpone the trip. At the same time, the amount of money to be refunded will depend on the time of contacting the carrier[13].

However, if it is possible to resolve issues on the territory of one's own state through agreements with the counterparty under the contract or through emergency measures taken by the President and the Government of the Russian Federation, then such issues may arise for Russian transport companies when performing contracts on the territory of foreign states. If a given country closes its borders or prohibits the entry of foreigners, then the prohibitive measures may be considered as force majeure circumstances that release the debtor from liability. But to confirm them, force majeure needs to be documented.

For foreign trade transactions, this is done, in particular, by means of a force majeure certificate. It is issued by the Chamber of Commerce and Industry of the Russian Federation. The internal contract parties can obtain the conclusion on the force majeure. To do this, the regional chamber should be contacted. Since March 26, 2020, these services have become free. However, this refers to attesting the circumstances that have arisen on the territory of our country. However, it is possible to try to send a request to the Russian Embassy, Consulate, or trade representative office, which can assist in obtaining official documents about force majeure from a foreign country. 
Considering the provisions of article 416 of the Civil Code of the Russian Federation, the obligation may also be terminated by the impossibility of its execution. Therefore, in the context of the coronavirus pandemic, responsibility for transport obligations should be determined on an individual basis. In this situation, it should be understood that the recognition of a circumstance as force majeure will not only release subjects from civil liability in the form of payment of penalties but may also lead to the insolvency of their counterparties.

Attention should be paid to the Federal law No. 166-FZ, which appeared on June 8, 2020, "On amendments to certain legislative acts of the Russian Federation in order to take urgent measures aimed at ensuring sustainable economic development and preventing the consequences of the spread of a new coronavirus infection". This legal act has made changes to almost all transport charters and codes, stating that "the Government of the Russian Federation under the threat of occurrence and (or) the occurrence of individual emergencies, the introduction of high alert or emergency in the whole territory of the Russian Federation or on the part of it has the right to establish in the relevant territory the specifics of the execution of the contract for the passenger carriage, including the right of the carrier to unilaterally change the terms of such an agreement or refuse to execute it and refund the fare for the passenger's travel and for the carriage of his baggage in the manner and terms established by the Government of the Russian Federation. This rule suggests that in general, the country's government is already preparing for such situations, which are likely to repeat in the future, and we can already talk not only about COVID-19, but also about other possible mass diseases that can paralyze the activities of not only transport companies, but also the world community as a whole for an indefinite period.

In case of refusal of the passenger from the carriage with the threat of occurrence and (or) the occurrence of individual emergencies, the introduction of high alert or emergency in the whole territory of the Russian Federation or its part the paid fare and baggage charges shall be refunded in the manner and terms established by the Government of the Russian Federation".

It seems that the discussion of issues related to the introduction of legal acts related to civil liability in the field of transport obligations should be carried out on a comprehensive scale. To begin with, it is necessary to create working groups and ask them questions about the admissibility of civil liability in conditions of force majeure, emergencies, unavoidability, etc. Then to create a single list of proposals with possible amendments to the civil legislation of Russia.

\section{Conclusion}

1. Based on the examples considered, as well as the norms of legislation changed in an emergency, it can be concluded that not always similar circumstances can be considered unavoidable in practice. This applies not only to individual obligations, but also to contracts in the field of transport obligations. Therefore, it is natural to assert that force majeure is an event, the consequences of which cannot be prevented under the given circumstances by any other similar participant in the modern civil circulation [14].

2. The result of the work of transport companies in the context of the coronavirus pandemic should be the introduction not only in local regulations, but in the norms of the Civil Code of provisions on the abolition of civil liability, or its partial abolition when establishing situations related to the introduction of self-isolation regimes, pandemics, etc. In this case, the CC RF should introduce a rule to cancel the liability of transport companies that transport passengers and baggage under contracts for the provision of transport services when an emergency or other regime is introduced that suspends their activities or 
terminates them based on a decision of the government of a subject of the Russian Federation or the state as a whole in order to preserve the life, health of citizens, security of a particular region and the state as a whole.

Such a rule should not apply to the responsibility of other organizations, in particular those operating in the agricultural sector, and those engaged in interstate transportation and transportation of perishable products, since such activities should be carried out in any conditions in order to prevent humanitarian disasters and maintain the conditions of normal life of citizens.

3. To stabilize the situation related to the return of funds spent by individuals for early booking, the purchase of tickets with various transport companies, it is critical on a mandatory basis to create in the latter special cash funds in reserve to resolve issues on the return of the ticket cost without affecting their further activities. In this regard, we consider it possible to introduce provisions in the Civil Code of the Russian Federation, Air laws regulations of the Russian Federation and the Federal law "On forwarding activity" mandatory to create reserve funds for reimbursement of costs of passengers tickets and transportation of goods in an aggregate amount equal to the possible liability limit.

\section{References}

1. A. Olisaeva, V. Dzobelova, S. Yablochnikov, O. Cherkasova, N. Davletbayeva, Formation and development of the digital economy in modern conditions development within the framework of industry 4.0. IDIMT-2019. Innovation and Transformation in a Digital World. (27 $7^{\text {th }}$ Interdisciplinary Information Management Talks Trauner Druck GmbH \& Co KG, Linz, 2019)

2. S. Yablochnikov, M. Kuptsov, S. Vidov, A. Olisaeva, The aspects of destructive influence of technical means and technologies of telecommunications on the person and society as a whole, CSIS'2019: Proceedings of the XI International Scientific Conference Communicative Strategies of the Information Society, 2, 1-6 (2019) https://doi.org/10.1145/3373722.3373766

3. Order of the Government of the Russian Federation dated 26.03.2020 "On the decisions following the meeting of the operational headquarters for the prevention of introduction and spread of new coronavirus infection in the Russian Federation" URL: http://government.ru

4. Order Oo the Governor of the Ryazan region dated March 17, 2020 No. 70-рг URL: https://rg.ru/2020/03/17/ryazan-rasp70-reg-dok.html

5. Decree of the President of the Russian Federation dated 25.03.2020 No. 206, URL: https://rg.ru/2020/04/02/prezident-ukaz239-site-dok.html

6. Decree of the President of the Russian Federation dated 28.04.2020 No. 294, 95 (2020)

7. Reference information: "Coronavirus (COVID-19). Measures of economic support for business in the regions of the Russian Federation" URL: http://www.consultant.ru/document/cons_doc_LAW_351744/

8. Rules for refund of air tickets and money due to coronavirus. URL: https://blogvoyage.ru/vozvrat-aviabiletov-i-deneg-iz-za-koronavirusa

9. Resolution of the Government of the Russian Federation dated 06.07.2020 N 991 (URL: http://www.consultant.ru/document/cons_doc_LAW_356669/781d780e32ba1e2da17d $56 \mathrm{f} 14 \mathrm{c} 20$ faed $5 \mathrm{fa} 4 \mathrm{c} 21 \mathrm{~d}$ 
10. M. Blinov, Airlines will be paid compensation for the export of Russians from other countries, RIA Novosti, URL: https://russian.rt.com/russia/news/732749aviakompanii-kompensacii-rossiyane.

11. The MFA of Russia published information about "export flights" for Russians, RIA Novosti, URL: https://russian.rt.com/russia/news/731644-reisy-mid-rossiyane (access date: 16.04.2020).

12. Transportation restrictions due to COVID-19, URL: https://www.telsgroup.ru/media_center/transport_news/5074.html

13. Railway tickets can be returned before June 1 without commission. URL: https://socprav.ru/vozvrat-zhd-biletov-v-kasse-rzhd-s-1-aprelya-po-1-iyunya-2020goda

14. V.A. Tarkhov, Civil law, (Cheboksary: Chuv. pub. house, 1997) 